\title{
Örgütsel Özdeşleşmenin İş Tatminine Etkisi: Burdur İlinde Bir Araştırma
}

\author{
Sefa CEYHAN* \\ Hüseyin ÇíÇEK***
}

Hatice GÖNÜLLÜ**

Meral BEKTAŞ S*** $^{* *}$

\begin{abstract}
$\ddot{O} Z$
Bireylerin kendisini işine, çalışma arkadaşlarına ve yöneticilerine bağgl hissetmesi durumunda örgütüyle özdeşleşmesi muhtemeldir. Ancak örgütü ile özdeşleşen her bireyin işinden tatmin olduğunu ifade etmek mümkün değidir. Bu sebeple örgütsel özdeşleşmenin iş tatmini üzerindeki etkisini belirlenmesi bu araştırmanın temel amacını oluşturmaktadır. Araştırmanın Burdur ilinde gerçekleştirilme sebebi ise alanda daha önce benzer nitelik taşıyan çalışma yapılmamış olması ve kamu çalı̧̧anlarının örgütsel özdeşleşme düzeylerinin tespit edilmemiş olmasıdır. Çalışmanın özgün yanını ifade eden bu kapsam doğrultusunda kamu çalışanlarından oluşan 285 kişiye yüz yüze anket çalışması uygulanmış, 34 kişi ile gerçekleştirilen görüşmenin yarıda kesilmesi sebebi ile 251 kişilik veri seti değerlendirmeye alınmıştır. Araştırma sonucunda örgütsel özdeşleşmenin iş tatminin örgüt boyutu ile hem anlamlı ilişkiye hem de anlaml etkiye sahip olduğu, ücret boyutu ile herhangi bir ilişki ya da etkiye sahip olmadiğı tespit edilmiştir. Bu tespit örgütsel özdeşleşme algısına sahip olan kamu çalışanlarının içinde bulundukları çalışma ortamından tatmin olduklarl ancak ücretin bu tatmin içerisinde yer almadiğl şeklinde yorumlanabilmektedir.
\end{abstract}

Anahtar Kelimeler: Örgütsel Özdeşleşme, İ̧s Tatmini, Kamu Kurumları

JEL Sinıflandirmast: D23, M10, M12, M54

\section{The Effect of Organizational Identification on Job Satisfaction: A Research in Burdur Province}

\begin{abstract}
If individuals feel devotion to their work, colleagues and managers, it is likely to be identified with their organization. However, it is not possible to state that each individual identified with his organization is satisfied with his work. Therefore, the main purpose of this research is to determine the effect of organizational identification on job satisfaction. The main reason for carrying out the study in Burdur is that there has not been any similar study in the area and the organizational identification levels of public employees have not been determined. This is the original side of the work. In line with this scope, 285 employees were interviewed face to face survey method, due to interrupting the interview with 34 people, the data set of 251 persons was taken into consideration.
\end{abstract}

\footnotetext{
*Doktora Öğrencisi, Burdur Mehmet Akif Ersoy Üniversitesi, İktisadi ve İdari Bilimler Fakültesi, İşletme Bölümü, ceyhansefa@hotmail.com, ORCİD Bilgisi: 0000-0002-3788-0756

** Yüksek Lisans Öğrencisi, Burdur Mehmet Akif Ersoy Üniversitesi, İktisadi ve İdari Bilimler Fakültesi, İşletme Bölümü, hatıcegonullu@ogr.mehmetakif.edu.tr, ORCİD Bilgisi: 0000-0002-8605-0839

***Doç. Dr. Burdur Mehmet Akif Ersoy Üniversitesi, İktisadi ve İdari Bilimler Fakültesi, İşletme Bölümü, hcicek@mehmetakif.edu.tr ORCID Bilgisi: 0000-0002-8284-7955

**** Dr. Öğr. Üyesi, Burdur Mehmet Akif Ersoy Üniversitesi, Sosyal Bilimler Meslek Yüksek Okulu, Büro Hizmetleri ve Sekreterlik Bölümü, mbektas@mehmetakif.edu.tr, ORCID Bilgisi: 0000-0002-1616-8065
}

(Makale Gönderim Tarihi: 27.03.2019 / Yayına Kabul Tarihi:01.03.2020) 
As a result of the study, it was determined that organizational identification had a significant relationship with the organizational dimension of job satisfaction and had no significant effect on the wage dimension. This finding can be interpreted that public employees who have a perception of organizational identification are satisfied with the work environment they are in, but that the wage is not included in this satisfaction.

Key Words: Organizational Identification, Job Satisfaction, Public Institutions

JEL Classification: D23, M10, M12, M54

\section{GíRIŞ}

Çalışma yaşamı, bireylerin çalışan rolleriyle dâhil oldukları, zihinsel ve bedensel etkinliklerini gerçekleştirdikleri sosyal bir ortamdır. Bu sosyal ortamda çalışanların işlerini tam anlamıyla benimseyebilmeleri ve kendilerinden beklenen verimliliğin sağlanabilmesi için bazı koşulların sağlanması gerekmektedir (Sirgy, 2001: 242). Örneğin iş gören yaptığı işten ekonomik, sosyal ve psikolojik olarak tatmin olabilmelidir. Bu tatmin sağlandığında, işyerinde bölüm veya gruplar arası dengenin bozulması ya da iş yavaşlatma gibi sorunlar yok edilerek, verimlilik ve etkinlik arttırılacaktır. Bu verimlilik ve etkinliliğin arttırılmasında örgütsel özdeşleşmenin de katkısının olduğu bilinmektedir (Marks vd., 1986: 69). Öte yandan işletmenin başarısı üzerinde rol oynayan bir diğer etken de iş tatminidir (Öktem vd., 2016: 163). Dolayısıyla örgütsel özdeşleşme ve iş tatmininin örgütün çalışma ortamı ve verimliliğinden, çalışanın fiziksel ve ruhsal sağlığını etkilemesine kadar göz ardı edilemeyecek derecede önemli olduğunu ifade etmek mümkündür (Özaydın ve Özdemir, 2014: 252). Bu önem doğrultusunda; çalışanların örgütsel özdeşleşmelerinin iş tatminleri üzerindeki etkisini incelemek araştırmanın temel amacını oluşturmaktadır.

\section{KURAMSAL ÇERÇEVE}

\section{A. Örgütsel Özdeşleşme}

Örgütsel özdeşleşme kavramı köken olarak sosyal kimlik teorisine dayanmaktadır (Bilgin, 1994: 224). Kimlik, bireylerin içinde yaşadıkları sosyal çevrelerinde kendilerini nasıl tanımladığını, nasıl konumlandırdığını, kim olduğunu ve nerede durduğunu yansıtan, onların inanç, tutum ve değer yargıları gibi yaşam biçimlerini sembolize eden geniş bir kapsama sahiptir (Stets ve Burke, 2000: 225). Sosyal kimlik, bireyin sosyal bir gruba üye olmaya yüklediği değerlerden oluşmaktadır (Fındık, 2011: 47). Bireylerin sosyal grupları kıyaslayarak daha olumlu değerlendirilen gruplara üye olmayı tercih ettiği görüşünü temel alan sosyal kimlik teorisi; sosyal sınıflandırma, sosyal karşılaştırma ve sosyal özdeşleşme olmak üzere üç bileşenden oluşmaktadır (İşcan ve Karabey, 2009: 40). Sosyal sınıflandırma, bireylerin kendilerini de dâhil ettikleri bir iç grup (biz) ve karşılarına aldıkları bir dış grup (onlar) sınıflaması yaparak sosyal çevrenin düzenlenmesidir (Demirtaş, 2004: 36). Bireyler kendilerini ve diğerlerini grup, din, cinsiyet, yaş gibi kategoriler altında sınıflandırma eğilimindedir. Sınıflandırma işlemi sonucunda gruplara ilişkin yargı kalıpları oluşur; yani bireyler kendi kişisel özelliklerinden ziyade içinde bulunduğu sınıfın özellikleriyle algılanırlar. Bu durum sosyal karşılaştırmanın bir sonucudur (Dominguez, 1977: 590). Bireyin grubunu ne kadar olumlu algıladığı, sosyal kimliğinin ne kadar olumlu olacağını belirtir. Bireyler 
olumlu bir sosyal kimlik edinmek için kendi gruplarını bir başka grupla karş1laştırırlar. Bu karşılaştırma sonucunda algılanan farkl111klar grubun lehine ise üyelerin sosyal kimliği bundan olumlu yönde etkilenirken, farkl11ıklar grubun aleyhinde olarak algılandığında üyelerin sosyal kimliği bundan olumsuz etkilenir (Sezici, 2010: 172). Şu halde bir gruba ait olma algısı olarak ifade edilen sosyal özdeşleşme, bireylerin içerisinde bulunduğu grupla bütünleşmelerini, sosyal çevrelerini düzenlemelerini ve bilişsel olarak sosyal çevrelerini ayırmalarını sağladığı ifade edilebilir (Gonzales, 2001: 32). Dolayısıyla sosyal özdeşleşme, bireylerin kendi değerlerine yakın gruplara üye olarak, öz saygı düzeylerini ve örgüte aitlik duygularını arttırabileceklerini ileri sürmektedir (Brehm ve Kassin, 1993: 102). Bir gruba kendi isteğiyle üye olan, bu üyelikten memnuniyet duyan ve aitlik hissi güçlü olan bireylerin, örgütle özdeşleşmeleri muhtemeldir (Kanten, 2012: 163). Örgütsel özdeşleşme, bireyin amaçlarının örgütün amaçlarıyla uyumlaşma sürecidir. Örgütleri ile özdeşleşen bireyler örgütlerinin başarı ve başarısızlıklarını kendilerine atfetmektedir (Bitmiş vd., 2013: 31). Diğer bir deyişle örgütsel özdeşleşme, bireylerin kendilerini örgüt ile fikir birliği içinde ve güvende olarak algılaması sonucu oluşan adanmışlık hissidir (Öz ve Bulutlar, 2009: 37). İşletmelerde örgütsel özdeşleşmenin neden önemli olduğu, özdeşleşmenin gerçekleşebilmesi için nasıl bir örgüt ortamının oluşturulması gerektiği ve yöneticilerin olaylara nasıl bakması gerektiğinin bilinmesi gerekir (Saruhan, 2017: 43). Bu bağlamda örgütsel özdeşleşmeye ilişkin yapılan kimi çalışmalardan elde edilen sonuçlar incelendiğinde; iş tatmini, motivasyon, performans, örgüte sadakat, işbirliği davranışı ve örgütsel vatandaşlık davranışı gibi kavramların örgütsel özdeşleşme ile doğrudan olumlu yönde ilişkiye sahip olduğu görülmektedir (Çetinkaya ve Çimenci, 2014: 273). Buradan hareketle örgütsel özdeşleşmenin bireye ve örgüte çeşitli olumlu sonuçlar getiren bir unsur olarak iş gücü verimliliğinin sağlanmasında belirleyici öneme sahip olduğu ifade edilebilir (Kanten, 2012: 192).

\section{B. İş Tatmini}

Sözlük anlamı itibariyle tatmin kavramı "istenen bir şeyin gerçekleşmesini sağlama, gönül doygunluğuna erme, doyum" olarak ifade edilmektedir (TDK, 2017). Gündelik dilde ise, birey tarafindan hissedilebilen haz ya da iç huzuru anlatmak için kullanılmaktadır (Yılmaz, 2015: 37). Bu haz ya da iç huzur, örgüt içerisinde çalışan bireylerin arzu ettikleri beklentilerine ulaşması neticesinde iş tatmini ile sonuçlanmaktadır (Görgülüer, 2013: 74). İş tatmini, çalışan kişi ile çalıştığ 1 iş yeri koşulları arasındaki uyumun sonucu olarak meydana gelen memnuniyet olarak ifade edilmektedir. Diğer bir deyişle, çalışanların işlerinden duydukları mutluluk iş tatminini oluşturmaktadır (Kovner vd., 2006: 78). Ancak bireyin her koşulda işinden mutluluk duyması mümkün olmayabilir. Böylesi durumlar tatminsizlik ile sonuçlanmaktadır (Demir, 2007: 98). Söz konusu tatmin ya da tatminsizliğe neden olan unsurlar bireysel ve örgütsel olmak üzere iki gruba ayrılmaktadır. Örneğin yaş, iş tatminine etki eden bireysel faktörlerden bir tanesidir. Literatürde yapılan çalışmaların pek çoğu, iş tatmini ile yaş arasında doğrusal bir ilişkinin olduğunu, yaş artıkça tatmin düzeyinin de arttığını ileri 
sürmektedir (Lee ve Wilbur, 1985: 781). Öte yandan iş tatminin bir diğer bireysel faktörü olan cinsiyet ile ilişkisi bağlamında yapılmış kimi çalışmalar da bulunmaktadır (Gündoğan, 2010: 12). Örneğin Urhan (2014) tarafindan gerçekleştirilen araştırma sonucunda çalışma hayatında yer alan kadınların eşi ve çocuklarına karşı sorumlulukları işe kendini vermesini engellemekte bu nedenle erkek çalışanlara göre iş tatminleri daha düşük olmaktadır. İş tatminini etkileyen bir diğer bireysel faktör de medeni durumdur. Kuo ve Chen (2014) tarafindan Tayvan'daki çalışanlar üzerinde yapılan araştırmada, evli çalışanların bekâr çalışanlardan daha fazla iş tatminine sahip oldukları sonucuna ulaşılmıştır. Cimete vd., (2003) tarafindan İstanbul'daki iki üniversite hastanesinde çalışan 501 hemşire üzerinde yapılan bir başka araştırma sonucunda ise, boşanmış veya dul çalışanların bekâr çalışanlara nazaran işlerinden daha fazla tatmin oldukları görülmüştür (Luddy, 2005: 113). Bu çalışmaların yanı sıra iş tatmininin eğitim ve kıdem üzerinde de etkili olduğunu ifade etmek mümkündür. Örneğin, bazı işlerde, yüksek öğrenim görmüş çalışanların, ortaöğretim ve ilkokul seviyesinde eğitim almış çalışanlardan daha az iş tatminine sahip oldukları bilinmektedir (Özaydın ve Özdemir, 2014: 256). Öte yandan uzun yıllar aynı işte olan bireyin diğer iş görenlere göre daha çok işinden memnun olduğu söylenebilir. (Türk, 2016: 10). İş tatmini ya da iş tatminsizliğine neden olan örgütsel faktörler incelendiğinde ise yapılan işin özelliği, çalışılan ortamın fiziksel koşulları, iş sağllğ 1 ve iş güvenliği, ücret ve terfi olanaklarının tatmin ya da tatminsizliğe neden olduğu ifade edilebilir. Örneğin yapılan işin özelliği bağlamında, işin birey tarafından ilgi çekici olarak algılanması, bireyin çalışırken kendini mutlu hissetmesi ve işin tekrar eden sıkıcı bir yapıda olmaması tatmin duygusunu artırmaktadır (Tayfun, 2015: 38). Öte yandan fiziksel çalışma koşullarının iyi olması iş tatmin düzeyini arttırmakta, kötü olması düşürmektedir (Keser, 2014: 151). İş tatmini ya da tatminsizliğine neden olan iş sağlığı ve iş güvenliği ise, çalışanların tehlike arz eden bir ortamda çalışmak istememesi ile ilgilidir. $\mathrm{Bu}$ doğrultuda çalışanların sağlık ve güvenliğinin korunmasına yönelik kimi çalışmalar bulunmaktadır. Örneğin, Türkiye mobilya endüstrisinde çalışanlar üzerinde yapılan bir araştırmaya göre; iş sağlı̆̆ 1 ve iş güvenliği eğitimi alanlar ile almayanlar arasındaki tatmin düzeyinde anlamlı bir fark olduğu tespit edilmiştir (Yıldırım vd., 2015: 183). Son olarak ücret ile iş tatmini arasındaki ilişki incelendiğinde, çalışanın aldığı ücretten memnun olması durumunda iş tatminin arttığ 1 aksi halde tatmin düzeyinin azaldığ (Doğar, 2013: 46). İş tatmininin sözü geçen bireysel ve örgütsel faktörlerinin yanı sıra öncül ve ardılları da bulunmaktadır. Örneğin iş tatmini çalışanlara yüksek moral sağlama, işe bağlanma, işyeriyle bütünleşme gibi bireysel sonuçlar sunmaktadır (Karakuş, 2011: 51). Bu bireysel sonuçlar kişinin içinde bulunduğu örgütle uyum içerisine olmasını ve örgütün amaçlarını benimsemesine yol açmaktadır (Kaplan, 2011: 133). İş tatmininin söz konusu olumlu sonuçlarının yanı sıra işe devamsızlık, yüksek iş gören devri, iş uyuşmazlıkları gibi olumsuz örgütsel çıktıları da bulunmaktadır. Bu sebeple yöneticilerin bahsi geçen olumlu ve olumsuz durumları dikkate almasının örgütün işlerliği açısından önem taşıdığını ifade etmek mümkündür (Sevimli ve İşcan, 2005: 59). 


\section{C. Örgütsel Özdeşleşme ile İş Tatmini Arasındaki İlişki}

Literatürde örgütsel özdeşleşme ve iş tatminine yönelik kimi çalışmalar bulunmaktadır. $\mathrm{Bu}$ çalışmalar kapsamında araştırma hipotezleri geliştirilmiştir. Örneğin; bilişim uzmanlarına yönelik yapılan bir araştırmada örgütleriyle özdeşleşmiş çalışanların iş tatminlerinin yüksek olduğu sonucuna ulaşılmıştır (Sökmen ve Bıyık, 2016: 226). Öte yandan otel çalışanları üzerinde yapılan bir başka çalışmada; iş görenlerin örgütsel özdeşleşme düzeylerinin arttıkça iş tatminlerinin de artacağ1, örgütsel özdeşleşme düzeyleri ne kadar düşük olursa iş tatminsizliğinin görülme sıklığının da o kadar yüksek olacağı sonucuna ulaşılmıştır (Morçin ve Çarıkçı, 2016: 108). Bu doğrultuda araştırmanın ilk hipotezi şu şekilde oluşturulmuştur; "H1: Örgütsel özdeşleşmenin iş tatmini üzerinde anlamlı bir etkisi vardır." Söz konusu araştırmalara benzerlik taşıyan bir başka çalışmada ise kamu kurumunda çalışan bireylerin iş tatmininin ve örgütsel özdeşleşme ile ilişkisi incelenmiş, araştırma kapsamında kamu kurumunda çalışan 304 kişi üzerinde anket çalışması uygulanmıştır. Araştırma sonucunda örgütsel özdeşleşmenin iş tatminini pozitif yönlü ve anlamlı bir şekilde etkilediği ortaya konulmuştur (Aypar, 2018: 121). Bu durumda örgütsel özdeşleşmenin iş tatminini arttıracağ 1 ve örgüte olumlu yönde çıktı sağlayacağı ifade edilebilir. Dolayısıyla araştırmanın ikinci hipotezi şu şekilde oluşturulmuştur; "H2: Örgütsel özdeşleşmenin iş tatmininin örgüt boyutu üzerinde anlamlı bir etkisi vardır. "Çalışanlar için bir diğer önemli faktörün ücret olduğunu belirten bir başka araştırmada; çalışanın işine olan tatmin düzeyini, aldığ ücretin yeterli olup olmaması, alması gereken ücrete oranla normalliği ve ihtiyaçlarını karşılayıp karşılamaması belirlediği ifade edilmektedir (Doğar, 2013: 46). Buradan hareketle araştırmanın üçüncü hipotezi şu şekilde oluşturulmuştur; "H3: Örgütsel özdeşleşmenin iş tatmininin ücret boyutu üzerinde anlamlı bir etkisi vardır."

\section{ARAŞTIRMANIN YÖNTEMI}

\section{A. Araştırmanın Modeli}

Araştırma hipotezlerin yorumlanmasını, araştırma verilerinin açklanmasını ve değişkenler arası görüntüyü somutlaştırmak adına Şekil 1'deki araştırma modeli oluşturulmuştur.

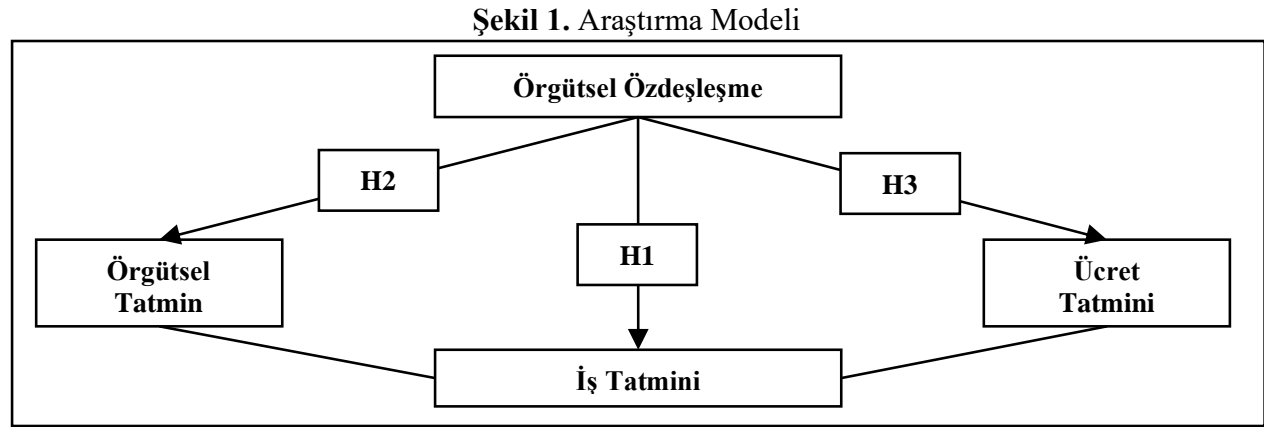

\section{B. Araştırmanın Evreni ve Örneklemi}

Örgütsel özdeşleşmenin iş tatmini üzerindeki etkisinin incelendiği bu araştırmanın evreni, Burdur ilinde görev yapmakta olan kamu personelinden 
oluşmaktadır. Ancak Burdur ilinde bulunan kamu personelinin aktif bir kaydı bulunmadığından evren hakkında net bir bilgiye ulaşılamamaktadır. Dolayısıyla Terzis ve Economides (2011) tarafindan ileri sürülen ana kütle sayısının belisiz olduğu durumlarda ölçekte yer alan ifade sayısının 10 katının örneklem belirleme sayısı için yeterli olduğu dikkate alındığında (Terzis ve Economides, 2011: 1038), bu araştırma için 170 kişilik örneklemin yeterli olduğu ifade edilebilir. $\mathrm{Bu}$ doğrultuda, Burdur ilinde görev yapmakta olan 285 kamu personeline ulaşılarak, yüz yüze anket çalışması gerçekleştirilmiştir. Bu çalışma neticesinde eksiksiz tamamlanan 251 kişilik veri seti değerlendirmeye alınmıştır.

\section{Araştırmanın Ölçüm Araçları}

Araştırma kapsamında ilk olarak Mael ve Ashforth (1992) tarafından geliştirilen, Tokgöz ve Seymen (2013) tarafından Türkçeye uyarlanan örgütsel özdeşleşme ölçeği kullanılmıştır. Söz konusu ölçek 6 madde ve tek boyuttan oluşmaktadır. Ölçeğin Cronbach Alfa güvenirlik katsayısı 0,918'dir. Cronbach Alpha değerlerine ilişkin bu araştırma kapsamında gerçekleştirilen analiz sonucunda, örgütsel özdeşleşme ölçeğinin güvenirlik katsayısı \%70 bulunmuştur $(\alpha=0,705)$. Ayrıca Skewness ve Kurtosis değerlerinin -1,000 ile $+1,000$ arasinda farkl11ık göstermesi (Hair vd., 2013) temel alınarak gerçekleştirilen normallik analizinde; örgütsel özdeşleşmenin Skewness değerinin -,352 ile ,154 arasında, Kurtosis değerinin -,320 ile ,306 arasında farklılık gösterdiği tespit edilmiştir. Bu doğrultuda söz konusu değerlerin faktör analizi için yeterli olduğu tespit edilmiş ve açımlayıcı faktör analizi uygulanmıştır.

Tablo 1. Örgütsel Özdeşleşme Ölçeğine İlişkin Faktör Analizi

\begin{tabular}{|c|c|}
\hline Örgütsel Özdeşleşme & \\
\hline 2. Çalıştığım kurum hakkında diğer insanların neler düşündüğü çok ilgimi çeker. & 0,587 \\
\hline $\begin{array}{l}\text { 3. Kurumum hakkında konuştuğum zaman, genellikle "onlar" ifadesindense "biz" kelimesini } \\
\text { kullanırım. }\end{array}$ & 0,582 \\
\hline 4. Çalıştığım kurumun başarısı benim başarımdır. & 0,714 \\
\hline 5. Biri, çalıştığım kurumu metheder veya överse, bu kişisel bir övgüymüş gibi hissederim. & 0,750 \\
\hline 6. Basında eğer çalıştığım kurumu tenkit eden bir hikâye varsa, utanırım. & 0,629 \\
\hline Varyansı Açıklama Yüzdesi: 44,984 & \\
\hline Açıklanan Toplam Varyans: 2,249 & \\
\hline
\end{tabular}

Tablo 1'de yer alan analiz sonuçlarında bir ifadenin diğer faktörlere aşırı yük bindirmesi sebebi ile değerlendirme dışı bırakılmıştır. İkinci kez gerçekleştirilen analiz sonucunda örgütsel özdeşleşme ölçeği orijinal formdaki gibi tek bir boyut altında toplanmıştır. Ayrıca Bartlett testinin yaklaşık ki-kare değeri 199,261 olduğu tespit edilmiştir. Gözlenen korelasyon katsayıları büyüklüğü ile kısmi korelasyon katsayılarının büyüklüğünü karşılaştıran bir indeks olan (Kalaycı, 2008: 322) söz konusu ki kare değeri, faktör analizinin kullanılmasının uygunluğunu göstermektedir. Gerçekleştirilen açımlayıcı faktör analizinin ardından yap1 geçerliliğini ölçmek amacıyla doğrulayıcı faktör analizi uygulanmıştır. Bu analiz sonucunda; Ki-kare $=13,425(\mathrm{df}=8, \mathrm{p}=0,098)$, RMSEA $=0,052, \mathrm{GFI}=0,982, \mathrm{AGFI}=0,953, \mathrm{NFI}=0,945, \mathrm{TLI}=0,956$, ve Ki-kare $/ \mathrm{df}=$ 1,510 değerleri bulunmuştur. 
Katılımcıların iş tatmin düzeylerinin ölçülmesi amacıyla Kısa Minessota İş Tatmin ölçeği kullanılmıştır. Söz konusu ölçek Weiss vd., (1963) tarafından geliştirilmiş, Özkan, (2016) tarafından Türkçeye uyarlanmıştır. 11 İfadenin yer aldığ1 ölçek, örgütsel tatmin ve ücret tatmini olmak üzere iki boyuttan oluşmaktadır. Güvenirlik değerlerine ilişkin bu araştırma kapsamında gerçekleştirilen analiz sonucunda, örgütsel tatmin boyutu 0,814 , ücret tatmini boyutu 0,805 ve genel güvenirlik değeri 0,820 bulunmuştur. İş tatmininin örgüt boyutunun ise Skewness değerinin -,258 ile,154 arasında, Kurtosis değerinin -,317 ile ,306 arasında olduğu tespit edilmişsir. Son olarak iş tatmininin ücret boyutunun Skewness değerinin -,164 ile,154 arasında, Kurtosis değerinin -,845 ile ,306 arasında farklılık gösterdiği belirlenmiştir (Hair vd., 2013). Bu doğrultuda söz konusu değerlerin faktör analizi için yeterli olduğu tespit edilmiş ve açımlayıcı faktör analizi uygulanmıştır. Sonuçlar Tablo 2'de yer almaktadır.

Tablo 2. İş Tatmini Ölçeğine İlişkin Faktör Analizi

\begin{tabular}{|c|c|c|}
\hline İş Tatmini & $\begin{array}{c}\text { Örgütsel } \\
\text { Tatmin }\end{array}$ & $\begin{array}{c}\text { Ücret } \\
\text { Tatmini }\end{array}$ \\
\hline 2. İşim yetenek ve becerilerimi kullanmamı sağlıyor &, 852 & \\
\hline 1. İşimi severek yapmaktayım. & ,837 & \\
\hline 11. Bu kurumda çalışmaktan memnunum & ,745 & \\
\hline 5. Yapığım işin sosyal hayatta saygınlığımı arttırdığını düşünüyorum. & ,618 & \\
\hline $\begin{array}{l}\text { 8. Bu işyerinde çalışanların iş güvenliği açısından gerekli tüm önlemlerin } \\
\text { alındığını düşünüyorum. }\end{array}$ & ,499 & \\
\hline 6. Bu kurumda çalışanlara yapılan işle ilgili teknik destek verilir. & ,493 & \\
\hline $\begin{array}{l}\text { 7. Çalıștı̆ıı ortamın fiziksel koşullarının (1sı, aydınlatma, temizlik, sağlığa } \\
\text { uygunluk vb.) uygun olduğunu düşünüyorum. }\end{array}$ & ,409 & \\
\hline 4. Bu kurumda terfiler kıdem esasına göre gerçekleşir. & ,401 & \\
\hline $\begin{array}{l}\text { 10. Aldığım ücret sosyal ihtiyaçlarım (tatil, sinema, sosyal faaliyetler) açısından } \\
\text { yeterlidir. }\end{array}$ & &, 850 \\
\hline $\begin{array}{l}\text { 9. Aldığım ücret fizyolojik (yeme, içme, barınma, sağlık, vb.) ihtiyaçlarımı } \\
\text { karşılamakta. }\end{array}$ & & ,815 \\
\hline Varyansı Açıklama Yüzdesi: & 37,701 & 13,548 \\
\hline Açıklanan Toplam Varyans: & 4,147 & 1,490 \\
\hline Kiser-Meyer-Olkin: 0,788 & ty: 1003,350 & \\
\hline
\end{tabular}

Tablo 2'de yer alan analiz sonuçlarında, örneklemin uygunluğu için bulunan Kaiser-Meyer-Olkin (KMO) değeri 0,788'dir. Bartlett test sonucunda yaklaşık ki-kare değeri ise 1003,350 çıkmaktadır. Bu değer faktör analizinin kullanılmasının uygunluğunu ifade etmektedir (Kalayc1, 2008: 322). Faktör analizinde tek bir sorunun diğer faktörlere aşırı yük bindirmesi sebebi ile değerlendirme dışı bırakılarak gerçekleştirilen ikinci analiz sonucunda iş tatmin ölçeği orijinal formdaki gibi iki boyut altında toplanmıştır. Elde edilen söz konusu değerlerin ardından yapı geçerliliğini ölçmek amacıyla doğrulayıcı faktör analizi uygulanmıştır. $\mathrm{Bu}$ analiz sonucunda; Ki-kare $=78,009(\mathrm{df}=32, \mathrm{p}=0,000)$, RMSEA $=0,076$, GFI $=0,940$, AGFI $=0,898, \mathrm{NFI}=0,915$, TLI $=0,926$, ve Kikare / $\mathrm{df}=2,438$ değerleri bulunmuştur. 


\section{ARAŞTIRMANIN BULGULARI}

\section{A. Demografik Bulgular}

Araştırmaya katılım gösteren çalıșanların \%33,5'ini oluşturan 84 kadın; $\% 66,5$ 'ini oluşturan 167 erkek bulunmaktadır. Bu katılımcıların \%80,5'i evli; \%19,5'i bekârdır. Ayrıca katılımcıların \%6'sı 18-25, \%35,9'u 26-35, \%28,3'ü 3645, \%27,1'i 46-55 ve \%2,8'i 56-61 yaş aralığındadır. 18-25 yaş aralı̆̆ındaki katılımcıların genelin \%6'sını oluşturması araştırmanın kamu kurumlarında yapılmasından kaynaklanmaktadır. Benzer şekilde 51-67 yaş aralığında çalışanların genelin \%2,8'ini oluşturması emeklilik yaşı bağlamında değerlendirilebilir. Çalışılan kurumdaki hizmet verilen süre incelendiğinde, kat1lımc1ların \%21,5'i 0-3 yı1, \%19,1'i 3-6 y1l, \%12,7'si 7-10 y1l, \%9,6's1 11-15 y1l, $\% 10,4$ 'ü 16-20 y1l, geriye kalan \%26,7'lik kısımın ise 21 y1l ve üzeri kurumda hizmet verdiği tespit edilmiştir. Son olarak katılımcıların eğitim durumlarının $\% 0,4$ 'ü ilkokul, \%1,6'sı ortaokul, \%10,4'ü lise, \%17,1'i ön lisans, \%57'si lisans, $\% 12,4$ 'ü yüksek lisans ve \%1,2'si doktora mezunu olduğu tespit edilmiştir. Elde edilen bu demografik bulguların yanı sıra örgütsel özdeşleşme ve iş tatmin ölçeğine ilişkin standart sapma ve ortalama değerler de incelenmiştir. Gerçekleştirilen analizler sonucunda örgütsel özdeşleşme ölçeğine ilişkin ortalama değer 3,6713 bulunmuş, standart sapmanın ise 0,7413 olduğu tespit edilmiştir. Benzer şekilde iş tatmininin örgütsel boyutunun ortalamasının 3,4329, standart sapma değerinin 0,7882 olduğu tespit edilmiştir. Son olarak iş tatmininin ücret boyutunun ortalamasının 3,0797, standart sapma değerinin 1,1565 olduğu tespit edilmiştir. Bu değerlerin yorumu ise Tablo 3'deki aralıklar dikkate alınarak yapılmıştır (Özdamar, 2003: 32).

Tablo 3. Aritmetik Ortalama ve İlişki Katsayı Aralıkları

\begin{tabular}{ccc}
\hline $1-1,79$ & Çok Düşük & $0,00-0,20$ \\
\hline $1,80-2,59$ & Düşük & $0,21-0,40$ \\
\hline $2,60-3,39$ & Orta & $0,41-0,60$ \\
\hline $3,40-4,19$ & Yüksek & $0,61-0,80$ \\
\hline $4,20-5,00$ & Çok Yüksek & $0,81-1,00$ \\
\hline
\end{tabular}

\section{B. Korelasyon Analizleri}

Araştırma değişkenlerinin ilişkisini incelemek adına gerçekleştirilen korelasyon analizi Tablo 4'de yer almaktadır. Korelasyon katsayıları yorumlanırken 0,00 ile 0,25 aralığındakikatsayıların çok zayıf, 0,26 ile 0,46 aralığındaki katsayıların zayıf, 0,50 ile 0,69 aralığındaki katsayıların orta, 0,70 ile 0,89 aralığındaki katsayıların yüksek ve 0,90 ile 1,00 aralığındaki katsayıların çok yüksek olduğu bilinmektedir (Köse, 2012: 227). Buna göre gerçekleştirilen analiz sonucunda; örgütsel özdeşleşmenin iş tatmininin örgüt boyutu ile pozitif yönlü ancak zayıf düzeyde anlamlı ilişkisi bulunurken $(\mathrm{r}=0,346 ; \mathrm{p}<0,001)$, iş tatmininin ücret boyutu ile herhangi bir ilişkisinin olmadiğ 1 tespit edilmiştir. $\mathrm{Bu}$ durum örgütsel olarak özdeşleşmiş bireylerin örgüt içerisinde uyumlu olacağı şeklinde yorumlanabilmektedir. 
Tablo 4. Araştırma Değișkenlerine İlişskin Korelasyon Analizi

\begin{tabular}{lccc}
\hline $\mathbf{n}=\mathbf{2 4 2}$ & $\mathbf{1}$ & $\mathbf{2}$ & $\mathbf{3}$ \\
\hline $\mathbf{1 .}$ Örgütsel Özdeşleşme & 1 & & \\
\hline 2. İş Tatmini Örgüt &, $346^{* * *}$ & 1 & \\
\hline 3. İş Tatmini Ücret &, 240 &, $393 * * *$ & 1 \\
\hline *** $<0,001 ; * * \mathrm{p}<0,01 ; * \mathrm{p}<0,05$ & & &
\end{tabular}

\section{Regresyon Analizleri}

Araştırma hipotezlerinin test edilmesi amacıyla gerçekleştirilen analizde örgütsel özdeşleşmenin iş tatmini üzerindeki etkisi \%10 düzeyinde 0,000 anlamlılık ile açılanabilmektedir $\quad\left(\mathrm{R}^{2}=0,102 ; \quad \mathrm{p}<0,001\right) . \quad$ Dolayısıyla "Örgütsel özdeşleşmenin iş tatmini üzerinde anlamlı bir etkisi vardır." şeklinde ifade edilen araştırmanın ilk hipotezi kabul edilmiştir. Örgütsel özdeşleşmenin iş tatmininin örgüt boyutu üzerindeki etkisi ise $\% 12$ düzeyinde 0,000 anlaml1lık ile açıklanabilmektedir $\left(\mathrm{R}^{2}=0,120 ; \mathrm{p}<0,001\right)$. Bu durum örgütsel özdeşleşmenin iş tatminin örgüt boyutu üzerinde pozitif etkisi olduğunu ifade etmektedir. Dolayısıyla "Örgütsel özdeşleşmenin iş tatmininin örgüt boyutu üzerinde anlamlı bir etkisi vardır." şeklinde ifade edilen araştırmanın ikinci hipotezi kabul edilmiştir. Son olarak örgütsel özdeşleşmenin iş tatminin ücret boyutu üzerindeki etkisini test etmek amacıyla gerçekleştirilen regresyon analizinde örgütsel özdeşleşmenin iş tatminin ücret boyutu etkilemediği görülmüştür. Bu durumda "örgütsel özdeşleşmenin iş tatmininin ücret boyutu üzerinde anlamlı bir etkisi vardır." ş̧eklinde ifade edilen araştımanın son hipotezi reddedilmiştir. Söz konusu sonuçlar Tablo 5'de yer almaktadır.

Tablo 5. Araştırma Hipotezlerinin Test Edilmesine İlişkin Regresyon Analizi Sonuçları

\begin{tabular}{|c|c|c|c|c|c|c|}
\hline \multirow{2}{*}{\multicolumn{2}{|c|}{ H1 }} & \multicolumn{5}{|c|}{ İş Tatmini } \\
\hline & & B & Std. Hata & B & t & p \\
\hline \multicolumn{2}{|c|}{ Sabit } & 2,181 & 0,228 & - & 9,546 & 0,000 \\
\hline \multicolumn{2}{|c|}{ Örgütsel Özdeşleşme } & 0,324 & 0,061 & 0,319 & 5,305 & 0,000 \\
\hline $\mathbf{R}=\mathbf{0 , 3 1 9}$ & $R^{2}=0,102$ & \multicolumn{2}{|c|}{$F=28,142$} & \multicolumn{2}{|c|}{$\begin{array}{c}\text { Durbin-Watson } \\
1,981\end{array}$} & $\mathbf{0 , 0 0 0}$ \\
\hline \multirow{2}{*}{\multicolumn{2}{|c|}{$\mathbf{H 2}$}} & \multicolumn{5}{|c|}{ İş Tatmini-Örgüt Boyutu } \\
\hline & & $\mathbf{B}$ & Std. Hata & B & t & $\mathbf{p}$ \\
\hline \multicolumn{2}{|c|}{ Sabit } & 2,083 & 0,237 & - & 8,798 & 0,000 \\
\hline \multicolumn{2}{|c|}{ Örgütsel Özdeşleşme } & 0,368 & 0,063 & 0,346 & 5,814 & 0,000 \\
\hline $\mathbf{R}=\mathbf{0 , 3 4 6}$ & $\mathbf{R}^{2}=\mathbf{0 , 3 2 0}$ & \multicolumn{2}{|c|}{$F=33,805$} & \multicolumn{2}{|c|}{$\begin{array}{c}\text { Durbin-Watson } \\
1,956\end{array}$} & $\mathbf{0 , 0 0 0}$ \\
\hline \multirow{2}{*}{\multicolumn{2}{|c|}{ H3 }} & \multicolumn{5}{|c|}{ İş Tatmini-Ücret Boyutu } \\
\hline & & B & Std. Hata & $\mathbf{B}$ & $\mathbf{t}$ & $\mathbf{P}$ \\
\hline \multicolumn{2}{|c|}{ Sabit } & 2,619 & 0,369 & - & 7,097 & 0,000 \\
\hline \multicolumn{2}{|c|}{ Örgütsel Özdeşleşme } & 0,125 & 0,099 & 0,080 & 1,273 & 0,204 \\
\hline $\mathbf{R}=\mathbf{0 , 3 1 9}$ & $R^{2}=0,102$ & \multicolumn{2}{|c|}{$F=1,621$} & \multicolumn{2}{|c|}{$\begin{array}{c}\text { Durbin-Watson } \\
1,996\end{array}$} & 0,006 \\
\hline
\end{tabular}

\section{SONUC VE ÖNERILER}

İnsan, işletmeyi kuran, yöneten ve orada çalışan kişidir. İnsan olmadan örgütsel bir başarıdan söz etmek mümkün değildir (Sabuncuoğlu ve Tokol, 2009: 17). Ancak insan unsurunun tek başına varlığ 1 kimi zaman yeterli olmamaktadır. Örgütlerin başarı sağlaması için işinden tatmin olmuş ve örgütü ile özdeşleşmiş insan gücüne ihtiyaç vardır (Turunç ve Çelik, 2010:184). Bu ihtiyaç doğrultusunda, 
bu araştırmanın temel amacı; örgütsel özdeşleşmenin iş tatmini üzerindeki etkisinin belirlenmesidir. Bu amaçla Burdur ilindeki kamu kurumu çalışanları üzerinde yüz yüze anket çalışması uygulanmıştır. Elde edilen sonuçlara göre örgütsel özdeşleşmenin iş tatmininin örgüt boyutu ile pozitif yönlü anlamlı bir ilişkiye sahip olduğu belirlenmiştir. Bu durum çalışanlarda örgütsel özdeşleşme arttıkça örgütsel tatmininin de artacağ 1 şeklinde yorumlanabilmektedir. Nitekim kamu kurumunda çalışan bireylerin iş tatmininin ve örgütsel özdeşleşme ile ilişkisinin incelendiği bir araştırmada da örgütsel özdeşleşmenin iş tatminini pozitif yönlü ve anlamlı bir şekilde etkilediği ortaya konulmuştur (Aypar, 2018: 121). Öte yandan otel çalışanları üzerinde yapılan bir başka çalışmada örgütsel özdeşleşme düzeylerinin arttıkça iş tatminlerinin de artacağ 1 sonucuna ulaşılmıştır (Morçin ve Çarıkçı, 2016: 108). Dolayısıyla bu araştırma sonucunda elde edilen söz konusu bulgunun literatürdeki diğer çalışmalarla da örtüştüğü ifade edilebilir. Örgütsel özdeşleşmenin iş tatmini üzerindeki etkisini ölçmeye yönelik gerçekleştirilen basit regresyon analizinde ise, örgütsel özdeşleşmenin hem iş tatmininin örgüt boyutu üzerinde hem de iş tatmini üzerinde anlamlı etkisinin olduğu tespit edilmiştir. Örgütleriyle özdeşleşmiş çalışanların iş tatminlerinin yüksek olduğu sonucuna ulaşılan (Sökmen ve Bıyık, 2016: 226) kimi çalışmalar da dikkate alındığında elde edilen bu sonucun literatürsel olarak anlamlı olduğu ifade edilebilir.

Örgütsel özdeşleşmenin iş tatmininin örgüt boyutunu açılarken, ücret boyutunu açıklayamadığ bu araştırma kapsamında elde edilen bir diğer sonuçtur. Oysa örgütsel özdeşleşmenin iş tatmininin ücret boyutu ile ilişkisini açılayan bir araştırmada, çalışanın işine olan tutumunun, aldığ ücret ile ilişkili olduğunu ifade edilmekteydi (Doğar, 2013: 46). Benzer şekilde örgütsel özdeşleşme, örgütsel bağlllık ve iş tatmini ilişkisinin incelendiği bir başka çalışmada, söz konusu değişkenler arasında pozitif yönlü ilişki bulunmuştur (Sökmen, 2019). Bu durum örgütleri ile özdeşleşmiş bireylerin işinden tatmin olduğu ve örgütsel bağl1lık yaşadığ1 şeklinde yorumlanabilmektedir. Bu noktada önemli bir sorun işinden tatmin olmuş ve örgütü ile özdeşleşmiş kamu personelinin stres, tükenmişlik yabancılaşma ya da sinizm gibi olumsuz tutum ve algılar ile örgütsel yaşama nasıl etkide bulunabildiğidir. Dolayısıyla sonraki çalışmalarda, söz konusu kavramlara ilişkinin örtük neden, süreç ve sonuçlarını anlamak için derinlemesine görüşmeler yoluyla nitel araştırmalar gerçekleştirilmesi önerilmektedir. Ayrıca araştırma örnekleminin Burdur ilinde görev yapan kamu personeli ile sinırlı olması bir kısıttır. Bu kısıtlamanın temel sebebi Türkiye de çalışmakta bulunan 2.713.703 kamu personeline (DPB, 2018) ulaşmanın hem zaman hem de maliyet bakımından mümkün olmaması ile ilgilir. Dolayısıyla tabakalı örneklem yöntemi ile yapılacak diğer çalışmaların ilgili literatüre katkı sağlayacağı düşünülmektedir.

\section{KAYNAKÇA}

Aypar, S. (2018)."Örgütsel Özdeşleşme, Tükenmişlik, Iş̧ Tatmini ve İşten Ayrllma Niyeti İlişkisi. Kamu Kurumunda Bir Araştırma", Gazi Üniversitesi, Sosyal Bilimler Enstitüsü, İşletme Ana Bilim Dalı, Yüksek Lisans Tezi, Ankara. 
Bitmiş, G. M., Sökmen, A. ve Turgut, H. (2013)."Psikolojik Dayanıklılığın Tükenmişlik Üzerine Etkisi: Örgütsel Özdeşleşmenin Aracılık Rolü", Gazi Üniversitesi İktisadi ve İdari Bilimler Fakültesi Dergisi, 15(2): 31.

Bilgin, N. (1994). Sosyal Bilimlerin Kavşağında Kimlik Sorunu, Ege Yayıncılık, İzmir.

Brehm, S. ve Kassin, S. M. (1993). Social Psychology, Houghton Mifflin Company Press, Boston.

Cimete, G. Gencalp, Nimet S. ve Keskin, G. (2003), "Quality of Life and Job Satisfaction of Nurses" Journal of Nursing Care Quality, 18(2), 151-158.

Çetinkaya, M. ve Çimenci, S. (2014)."Örgütsel Adalet Algısının Örgütsel Vatandaşlık Davranışı Üzerindeki Etkisi ve Örgütsel Özdeşleşmenin Aracılık Rolü: Yapısal Eşitlik Modeli Çalışması", Yönetim Bilimleri Dergisi, 12(23): 248-273.

Demir, N. (2007). Örgüt Kültürü ve İş tatmini, Türkmen Kitapevi, İstanbul.

Demirtaş, A.H. (2004). "Sosyal Sınıflandırma, Kişilerarası Beklentiler ve Kendini Doğrulayan Kehanet", Iletişsim Araştırmaları, 2(2), 33-53.

Devlet Personel Başkanlığı (2018). http://www.dpb.gov.tr/tr-tr/istatistik/kamu-personelinin-butceturlerine-gore-calisan-sayisinin-dagilimi-504, 01.11.2019.

Doğar, N. (2013). Kişilik, Örgütsel Bağlllık ve İş Tatmini Arasındaki İlişkilerin İncelenmesi: İstanbul'da Faaliyet Gösteren İki Ticarî Bankada Bir Araştırma, Çukurova Üniversitesi, Sosyal Bilimler Enstitüsü, İşletme Ana Bilim Dalı, Doktora Tezi, Adana.

Dominguez, V. (1993). White by Definition: Social Classification in Creole Louisiana, Rutgers University Press, New Jersey.

Fındık, M. (2011)."Algllanan Örgütsel Desteğin, Örgütsel Özdeşleşme ve İșten Ayrılma Niyetine Etkisi Araştırması: Konya Aile Hekimleri Örneği", Sosyal Bilimler Enstitüsü, İşletme Ana Bilim Dalı, Yönetim ve Organizasyon Bilim Dalı, Yüksek Lisans Tezi, Selçuk Üniversitesi, Konya.

Gonzales, J. A. (2001)."Personal and Identity in Organizations: A Study of Organizational Commitment", Doctoral Dissertion, Texas University, Texas.

Görgülüer, A. A. (2013)."Örgütsel Adalet ve İş Tatmininin Örgütsel Bağlllı̆̆a Etkisi Üzerine Bir Araştırma", Niğde Üniversitesi, Sosyal Bilimler Enstitüsü, İşletme Ana Bilim Dalı, Yönetim ve Organizasyon Bilim Dalı, Yüksek Lisans Tezi, Niğde.

Gündoğan, T. (2010). "İş Tatmini ve Örgütsel Bağlllık: Bir İnsan Kaynakları Bölümünde Uygulama", Ankara Üniversitesi, Sosyal Bilimler Enstitüsü, İşletme Ana Bilim Dalı, Yüksek Lisans Tezi, Ankara.

Hair, J. F., Ringle, C. M. ve Sarstedt, M. (2013)."Partial Least Squares Structural Equation Modeling: Rigorous Applications", Better Results and Higher Acceptance.16(3): 146-198

İşcan, Ö. F. ve Karabey, Canan, N. (2009). "Örgütsel Özdeşleşme", Edt. Aşkın Keser, Gözde Yılmaz ve Senay Yürür, Çalışma Yaşamında Davranış Güncel Yaklaşımlar, Umuttepe Kitapevi, Kocaeli.

Kalaycı, Ş. (2006). SPSS Uygulamalı Çok Değişkenli İstatistik Teknikleri, Asil Yayınevi, Ankara.

Kanten, P. (2012). "İşgörenlerde İşe Adanmanın ve Proaktif Davranışların Oluşumunda Örgütsel Güven ile Örgütsel Özdeşleşmenin Rolü", Süleyman Demirel Üniversitesi, Sosyal Bilimler Enstitüsü, İşletme Ana Bilim Dalı, Doktora Tezi, Isparta.

Kaplan, İ. (2011)."Örgütsel Vatandaşlık Davranışı ve İş Tatmini İlişkisi; Konya Emniyet Teşkilatı Üzerinde Bir Uygulama", Selçuk Üniversitesi, İşletme Ana Bilim Dalı, Yönetim ve Organizasyon Bilim Dal,, Doktora Tezi, Konya.

Karakuş, H. (2011). "Hemşirelerin İş Tatmin Düzeyleri: Sivas İli Örneği", Dicle Üniversitesi Sosyal Bilimler Enstitüsü Dergisi, 3(6): 51.

Keser, A. (2014). Çalışma Psikolojisi, Ekin Yayınevi, Bursa.

Kovner, C. Brewer, C. W. U., Yow, W., Cheng, Y., ve Suzuki, M. (2006)."Factors Associated with Work Satisfaction of Registered Nurses", Journal of Nursing Scholarship, 38(1), 71-79.

Köse, S. Kartal, B. ve Kayalı, N. (2003). "Örgütsel Vatandaşlık Davranışı ve Tutuma İlişkin Faktörlerle İlişkisi Üzerine Bir Araştırma", Erciyes Üniversitesi İktisadi ve İdari Bilimler Fakültesi Dergisi, 20(2): 1-19. 
Kuo, Y. F. ve Chen, L. S. (2004). "Individual Demographic Differences and Job Satisfaction Among Information Technology Personnel: An Empirical Study in Taiwan", International Journal of Management, 21(2), 221-231.

Lee, R. ve Wilbur, E. R. (1985). "Age, Education, Job Tenure, Salary, Job Characteristics, and Job Satisfaction: A Multivariate Analysis", Human Relations, 38(8): 781.

Luddy, N. (2005) Job Satisfaction Amongst Employees at a Public Health Institution in the Western Cape, University of the Western Cape, Master Thesis, Republic of South Africa.

Marks, M. L., Mirvis, P. H., Hackett, Edvard, J. ve Grady, J. F. (1986). "Employee Participation in a Quality Circle Program: Impact on Quality of Work Life, Productivity, and Absenteeism", Journal of Applied Psychology, 71(1), 61.

Mael, F. ve Ashforth, B.E. (1992), "Alumni and Their Alma Mater: a Partial Test of the Reformulated Model of Organizational Identification", Journal of Organizational Behavior, 13(2), 23103.

Morçin, S.E. ve Çarıkçı, İlker, H. (2016). "Dönüştürücü/Etkileşimci Liderliğin İş Tatminine Etkisinde Örgütsel Özdeşleşmenin Aracılık Rolü: Antalya'daki Beş Yıldızlı Otel İşletmeleri Örneği", Süleyman Demirel Üniversitesi İktisadi ve İdari Bilimler Fakültesi Dergisi, 21(1): 97-108.

Öktem, Ş. ve Kızıltan, B. (2016). "Örgütsel Güven ile Örgüt İkliminin Örgütsel Özdeşleşme, İş Tatmini ve İşten Ayrılma Niyeti Üzerine Etkileri: Otel İşletmelerinde Bir Uygulama", İşletme Araştırmaları Dergisi, 8(4): 163.

Öz, E. Ü. ve Bulutlar, F. (2009)."Algılanan Kurumsal İtibar ve Kurumdan Ayrilma Niyeti Arasındaki İlişskide Bir Ara Değişken Olarak Özdeşleşmenin Rolü", Yönetim Araştırmaları Dergisi, 9(1): 37.

Özaydın, M. M. ve Özdemir, Ö. (2014). "Çalışanların Bireysel Özelliklerinin İş Tatmini Üzerindeki Etkileri: Bir Kamu Bankası Örneği”, İşletme Araştırmaları Dergisi,6(1): 256.

Özkan, S. (2016)."Taşeron Personel ile Kadrolu Personelin Örgütsel İletişim, Örgüt Kültürü ve Işs Tatmini Değişkenleri Açısından İncelenmesi: Giresun Belediyesi Örneği", Avrasya Üniversitesi, İşletme Ana Bilimi Halkla İlişkiler Bỉlim Dalı, Yüksek Lisans Tezi, Trabzon.

Özdamar, K. (2003). Modern Bilimsel Araşstırma Yöntemleri: Araştırma Planlama, Toplum ve Örnek Seçimi, Güç Analizi, Proje Hazırlama, Veri Toplama, Veri Analizi, Bilimsel Rapor Yazımı. Kaan Kitabevi.

Sabuncuoğlu, Z., ve Tokol, T. (2009). Genel Işsletme, Alfa Aktüel Basım, Bursa.

Saruhan, S. (2017)."Örgütsel Sosyalleşmenin Örgütsel Özdeşleşme Üzerindeki Etkisi", Kırıkkale Üniversitesi, İşletme Ana Bilim Dalı, Yönetim ve Organizasyon Bilim Dalı, Yüksek Lisans Tezi, Kırıkkale.

Sezici, E. (2010). “Örgütsel Özdeşleşme”, Edt. D. Ergun Özler, Örgütsel Davranışta Güncel Konular, Ekin Yayınevi, Bursa.

Sevimli, F. ve İşcan, Ö. F. (2005). "Bireysel ve İş Ortamına Ait Etkenler Açısından İş Doyumu", Ege Akademik Bakış Dergisi, 1(5): 58-59.

Sirgy, J. M., Efraty, D. Siegel, P. ve Lee, D. J. (2001). "A New Measure of Quality of Work Life (QWL) Based on Need Satisfaction and Spillover Theories", Social Indicators Research, 55(3), 241-302.

Sökmen, A. ve Bıyık, Y. (2016). "Örgütsel Bağl1lık, Örgütsel Özdeşleşme, Kişi-Örgüt Uyumu ve İş Tatmini İlişkisi: Bilişim Uzmanlarına Yönelik Bir Araştırma", Bilişim Teknolojileri Dergisi, 9(2): 221-226.

Sökmen, A. (2019). “Örgütsel Özdeşleşme, Örgütsel Bağlllık ve İş Tatmini İlişkisi”, Journal of Tourism and Gastronomy Studies, 7(2): 980-990.

Stets, J. E. ve Burke, P. J. (2000). "Identity Theory and Social Identity Theory", Social Psychology Quarterly, 63(3): 224-237.

Tokgöz, E., ve Seymen, O. A. (2013). "Örgütsel Güven, Örgütsel Özdeşleşme ve Örgütsel Vatandaşlık Davranışı Arasındaki İlişki: Bir Devlet Hastanesinde Araştırma", Öneri Dergisi, 10(39), 61-76.

Tayfun, A. (2015)."Örgütsel Sessizliğin Örgütsel Bă̆lllık ve İş Tatmini Üzerindeki Etkisi, Gazi Üniversitesi", İşletme Ana Bilim Dalı, Yönetim ve Organizasyon Bilim Dalı, Yüksek Lisans Tezi, Ankara. 
Terzis, V. ve Economides, A. A. (2011). "The Acceptance and Use of Computer Based Assessment", Computers \& Education, 56(4): 1032-1044.

Tiktaş, G. (2012). "Örgüt Kültürü, Örgütsel Özdeşleşme ve Örgütsel Sessizlik İlişkisine Yönelik Bir Inceleme", Dokuz Eylül Üniversitesi, İşletme Ana Bilim Dalı, Yönetim ve Organizasyon Bilim Dalı, Doktora Tezi, İzmir.

Turunç, Ö. ve Çelik, M., (2010), "Çalışanların Algıladıkları Örgütsel Destek ve İş Stresinin Örgütsel Özdeşleşme ve İş Performansına Etkisi", Celal Bayar Üniversitesi İktisadi ve İdari Bilimler Fakültesi Yönetim ve Ekonomi Dergisi, 17(2), 184.

Türk, F. (2016). "İş Tatmini ve Örgütsel Bağlllık Illişkisi: Kamu Çalışanlarına Yönelik Bir Araştırma", NişantaşıÜniversitesi, Sosyal Bilimler Enstitüsü, İşletme Ana Bilim Dalı, Yüksek Lisans Tezi İstanbul.

Türk Dil Kurumu, (2018) http://www.tdk.gov.tr, 21 Ekim 2017.

Urhan, S. (2014). "İ̧̧ Tatmini ve Örgütsel Bağlılık İlişkisi Bir Alan Araştırması", Pamukkale Üniversitesi, İşletme Ana Bilim Dalı, Yönetim ve Organizasyon Bilim Dalı, Yüksek Lisans Tezi, Denizli.

Weiss, D. J., Dawis, R. V., ve England, G. W. (1967). Manual for the Minnesota Satisfaction Questionnaire. Minnesota Studies in Vocational Rehabilitation.

Yıldırım, İ. Akyüz, K. C., Akyüz, İ. ve Alevli, C. (2015). "Mobilya Sektöründe Çalışanların İş Güvenliği Algıları ve İş Doyumu Düzeylerinin İncelenmesi", 3. Ulusal Mobilya Kongresi, Konya.

Yılmaz, E. (2015). "Hastanelerde Kadın Çalışanlara Yönelik Psikolojik Yıldırma (Mobbing) ve İş Tatminine Etkisi: Isparta İlinde Bir Uygulama", Süleyman Demirel Üniversitesi, Sosyal Bilimler Enstitüsü, İşletme Ana Bilim DalıYüksek Lisans Tezi, Isparta.

\section{SUMMARY}

Working life is a social environment in which individuals are usually involved in their working roles and realize their mental and physical activities. The act of action is of great importance for both the individual and the society because it is an area where individuals spend most of their time in the work environment and earn income to survive. This area, where the individual turns into a productive structure with knowledge, skills and abilities, has significant economic, social and psychological effects on individuals, organizations and society. In this study, the effect of organizational identification on job satisfaction was investigated. In the scope of this research, a survey was applied to public employees in Burdur province and the results were analyzed. In the results of the analysis, it was determined that organizational identification was positively correlated with the organizational dimension of job satisfaction. This situation can be interpreted that the individuals identified with the institution are satisfied with the organizational conditions. Indeed, individuals can be identified with their organization if they feel connected to their work, colleagues and managers. They may be satisfied with their job depending on their general attitude towards the employee organization. Therefore, the individuals identified with the organization are not expected to experience organizational dissatisfaction. However, it is not possible to talk about the existence of the same meaningful relationship between the organizational identification and the correlation analysis for the wage dimension of job satisfaction. Therefore, it is not possible to state that each individual identified with his organization is satisfied with the wages he has earned. On the other hand, simple regression analysis was conducted to measure the effect of organizational identification on job satisfaction. According to the results, it was determined that organizational identification had an 
effect on the organizational dimension of job satisfaction, but that job satisfaction had no effect on the wage dimension. This also coincides with the results obtained in the correlation analysis. Therefore, it is found that the individuals who are identified with the organization are satisfied in the organizational sense but that there is no relation or effect in the context of the wage received. 